\title{
Using Pedotransfer Function (PTF) analysis in the assessment of the parameters of potential radionuclide transport through the vadose zone of PRAW "Novi Han" - an initial stage of a model case study
}

\author{
Dimitar Antonov ${ }^{1}$, Nikolay Stoyanov², Aleksey Benderev ${ }^{1}$ \\ ${ }^{1}$ Geological Institute, Bulgarian Academy of Sciences, Acad. G. Bonchev Str., Bl. 24, 1113 Sofia, Bulgaria; \\ e-mail:dimia@geology.bas.bg; alekseybenderev@yahoo.com \\ ${ }^{2}$ University of Mining and Geology, Department of Hydrogeology and Engineering Geology, Studentski Grad, \\ Prof. Boyan Kamenov Str., 1700 Sofia, Bulgaria; e-mail: nts@mgu.bg
}

(Accepted in revised form: May 2019)

\begin{abstract}
The Repository for Radioactive Waste in Novi Han, Lozen Mountain (Bulgaria), dates from the early 1960s. In the present study, the complex geoenvironmental setting of the repository site was analysed from the viewpoint of assessment of potential radionuclide migration from the repository to the geosphere. Thus, components of the mass transport field were elaborated as a part of a conceptual model. In connection with this, a detailed characterization of the subsurface, especially of the vadose zone around the repository, was performed. The fractions of sand, silt and clay based on the grain-size distribution curves of samples from the different hydrogeological units gathered on the site of RAW-Novi Han were implemented in the ROSETTA program, and the respective hydraulic parameters were determined. As a result, the entire vadose zone was hydraulically determined.
\end{abstract}

Antonov, D., Stoyanov, N., Benderev, A. 2019. Using Pedotransfer Function (PTF) analysis in the assessment of the parameters of potential radionuclide transport through the vadose zone of PRAW “Novi Han” - an initial stage of a model case study. Geologica Balcanica 48 (2), 3-12.

Keywords: vadose zone, unsaturated flow, parameter estimation, ROSETTA, radioactive waste.

\section{INTRODUCTION}

The Repository for Radioactive Waste (RAW) in Novi Han, Lozen Mountain (Bulgaria), further noted as RAW-Novi Han, dates from the early 1960. Its purpose is the storage of unconditioned waste from the medicine, military sources, and scientific research activities in desolate site relatively close to the capital region. The official exploration of the repository started in 1964 with few $\mathrm{m}^{3}$ and up until 2010 the gross volume of the waste went up to around $670 \mathrm{~m}^{3}$ (Nuclear Regulatory Agency, 2011). In addition, according to the Bulgarian Strategy for Spent Fuel and Radioactive Waste Management SSFRAWM, the RAW-Novi Han will be subject to closure after the New National RAW Repository starts operations to accept the respective waste there (Council of Ministers, 2011).

According to international documents, e.g., those of the International Atomic Energy Agency IAEA, such facilities should present a multibarrier approach ("defense in depth") in order to ensure the safety of operations during and after the exploitation period (IEAE, 2006).

The choice of the RAW-Novi Han site was made in the early 1960s on the basis of expert evaluation of several sites. Being a "Radon" type facility, RAWNovi Han's engineered barriers represent specific units constructed from reinforced concrete and additional barriers such as steel layers, bitumen layers and brick walls (Mateeva, 2001). Although the geosphere around the ground site should be considered 
as a main barrier against unanticipated radionuclide migration in the future decades (Stefanova, 2003), up until the 1990s there were not any in-depth geological, engineering geological and hydrogeological investigations concerning the aspects of transport of radionuclides from the viewpoint of a geoenvironmental impact of the repository site (Evstatiev and Kozhoukharov, 2000).

The first survey focused on the geosphere properties around the RAW-Novi Han was performed in 1992 - a complex assessment of the geological and geotechnical conditions of the repository site (Evstatiev et al., 1994; Evstatiev and Kozhoukharov, 2000), followed by a detailed investigation between 2000 and 2002 of the geological, engineering geological and hydrogeological conditions on and along the repository site (Kozhoukharov et al., 2002; Vassilev and Kozhoukharov, 2004). The last two studies were undertaken according to the documents of the IAEA, e.g., IAEA 1994 and IAEA 1999 (both documents are superseded by IAEA, 2014, and IAEA, 2011, respectively), and the national regulations and legislation (Kozhoukharov et al., 2002).

Based on the results of the last investigation, there is a preliminary research of four radionuclides fate and transport in the saturated part of the profile based on laboratory determination of their distribution coefficients (Galabov et al., 2003). A second research work was based on "Interaction Matrix of System of Processes and Phenomena" modelling (Mateeva and Antonov, 2004). The methodology of the latter relies on the general description of natural conditions by applying such values of parameters which will lead to conservative results (IAEA, 2004). In a more recent study, the characteristics of the geosphere were analyzed from the viewpoint of the long-term stability of the repository (Antonov and Varbanov, 2013).

In summary, there are studies concerning some aspects of the natural conditions of the site, but there is no research work integrating the sources, the vadose and phreatic zones with their specific characteristics.

The aim of the study is to evaluate the parameters of both the vadose and saturated zones as a part of conceptual model and thus to provide detailed characterization of the subsurface around the repository.

As a further study, the potential radionuclide transport through the vadose zone will be studied based on the conceptual model, using numerical modeling with two different scenarios: with existing radioactive waste storage facilities and without such an inventory.

\section{GEOENVIRONMENTAL SETTING}

\section{Geosphere}

\section{Geological and engineering geological setting}

The RAW-Novi Han is located in the Lozen Mountain, where the geological structures of the area consist of Lower Paleozoic, Upper Paleozoic, Lower Triassic, Neogene and Quaternary deposits, and several magmatic bodies of granitoids and lamprophyre dykes (Fig. 1) (Vassilev and Kozhoukharov, 2004). Due to the purpose of the study, the engineering geological setting of the site area will be presented in details. According to the performed surveys (Kozhoukharov et al., 2002; Antonov and Varbanov, 2013), four engineering geological zones (EGZ) are identified, distinguished both in planview and in cross-section of the site (Figs 2, 3).

\section{Hydrogeological setting}

Regarding the hydrogeological conditions of both the ground site of RAW-Novi Han and the area along it, two zones subject to different hydraulic characteristics are presented. A relatively thick unsaturated zone exists in the upper part of the ground site profile incorporating the whole anthropogenic zone and a part of the highly weathered zone. Downwards, in the weathered part of the phyllite massive, an aquifer is developed that is recharged only by precipitation. The flow shows a strict direction to the north (Fig. 4). The mean annual infiltration recharge for the area is assessed as $29.3 \mathrm{~mm}$, the total groundwater recharge $-0.7 \mathrm{l} / \mathrm{s}$ (for area of $0.75 \mathrm{~km}^{2}$ ), hydraulic gradient -0.095 , and the average aquifer transmissivity $-0.3 \mathrm{~m}^{2} / \mathrm{d}$ (Kozhoukharov et al., 2002).

\section{Definition of the mass transport model}

Based on the hydrogeological setting of the repository site, as well as the position of the storage facilities and engineered barriers, a convective-dispersive model of the water flow, which accounts for the retardation properties of the engineered layers and the geosphere, should be developed. Such models have been applied in similar studies in Bulgaria (Stoyanov, 2009, 2012; Antonov, 2017) and abroad (e.g., Robinson and Bussod, 2000; Mallants et al., 2001; Šimůnek et al., 2006; Mallants et al., 2011; Merk, 2012; Piqué et al., 2013).

Regarding the aim of the whole investigation, as a next step, the model should be implemented in two scenarios: with stored wastes (with some arbitrary values for radionuclide concentration) and 


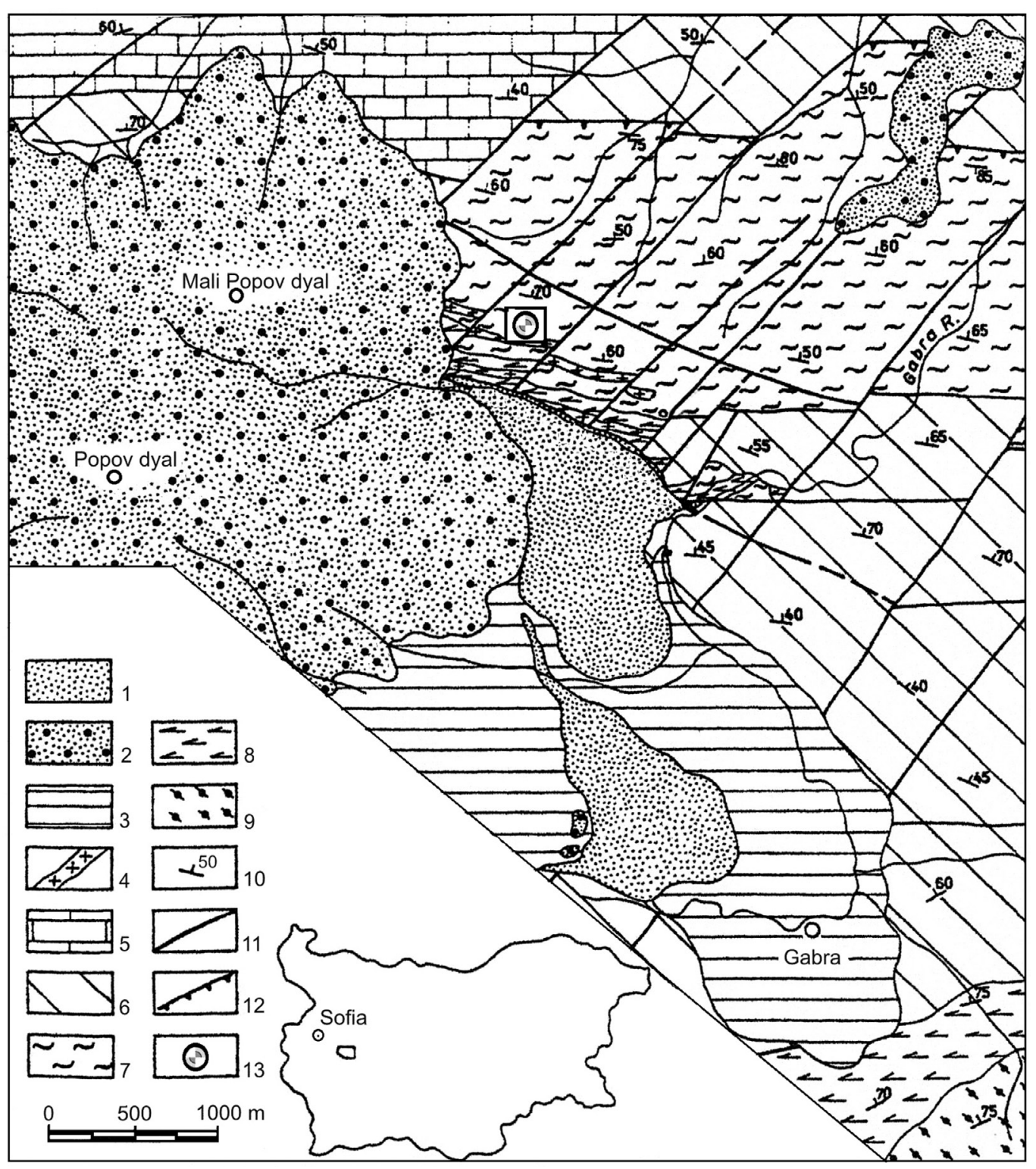

Fig. 1. Geological map of the RAW Repository Novi Han, Lozen Mountain (after Vassilev and Kozhoukharov, 2004, with amendments): 1 - Deposits formed by human activity; 2 - Popov Dyal Formation (Late Miocene-Early Pliocene); 3 - Unit of the argillaceous sandstones and clays of the Chukurovo coal layers (Miocene-Helvetian); 4 - Upper Cretaceous dykes of syenite-granite porphyry; 5 - Triassic sediments; 6 - Upper Carboniferous and Permian sediments; 7 - Phyllite schists and phyllite unit (Ordovician); 8 - Diabase-phyllitoid complex (Late Riphean-Vendian); 9 - Precambrian metamorphic rocks of the Arda Group; 10 - Bedding; 11 - Fault; 12 - Reverse fault; 13 - RAW Repository Novi Han.

with removed waste but contaminated subsurface soil layer(s).

\section{Elements of the Mass Transport Field - conceptual model}

In order to achieve its goals, i.e., to perform a reliable assessment of the radionuclide migration, the model should consider the following elements:

- Engineered barriers. According to the international safety requirements, the engineered barriers are subject to destruction after 100 years of usage of the waste facility. Due to the operation period of RAW-Novi Han (since 1964), this period is halved. On one hand, the barrier is still in operation and, on the other, appearance of some cracks and fissures in the concrete parts is possible. For the purpose of the study, the model takes into account an arbitrary value of the radioactive concentration into the pore water as an outflow from the bottom of the facilities.

- Vadose zone. The vadose zone coincides with the embankment (anthropogenic zone) and with the 


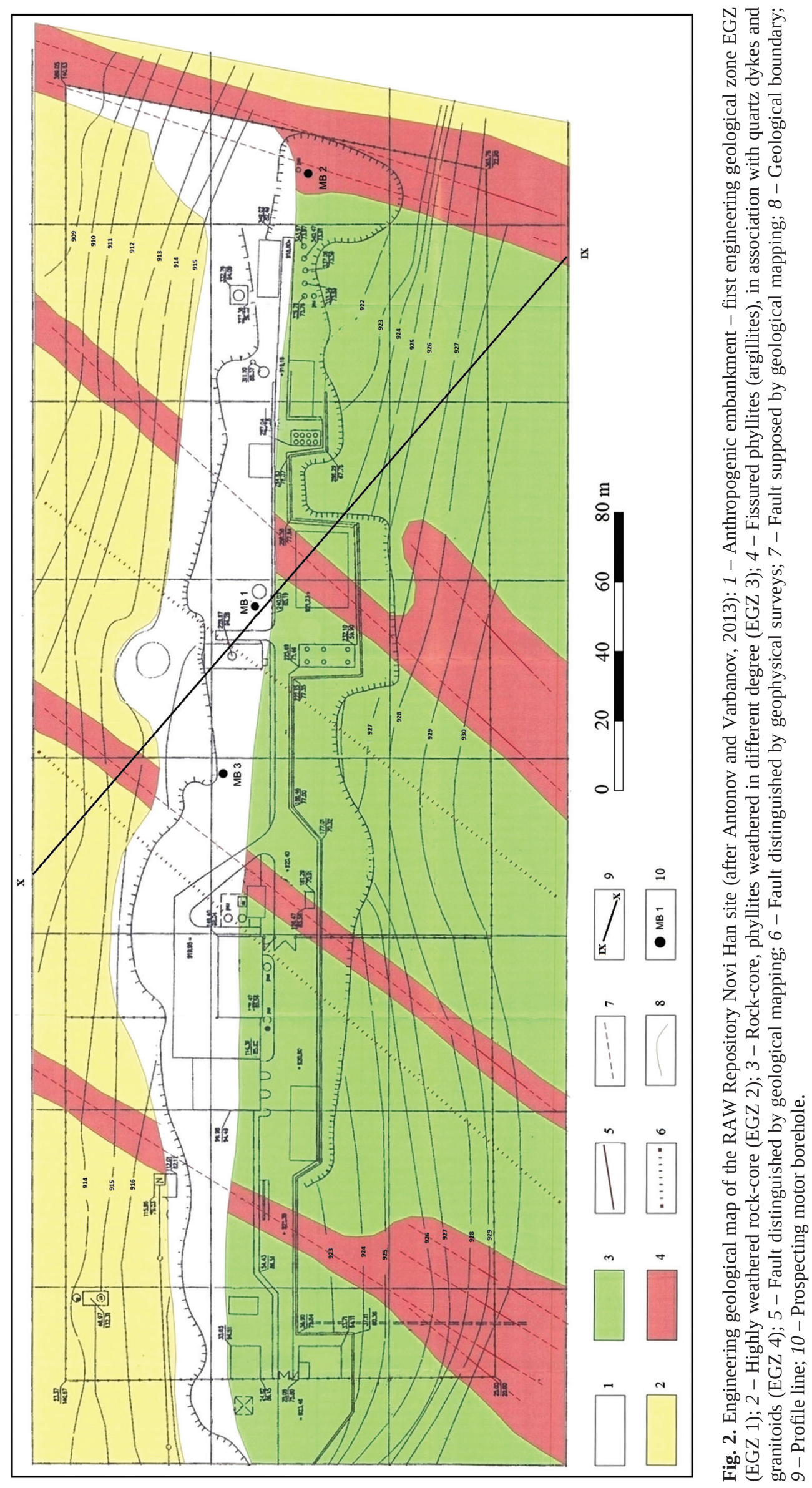




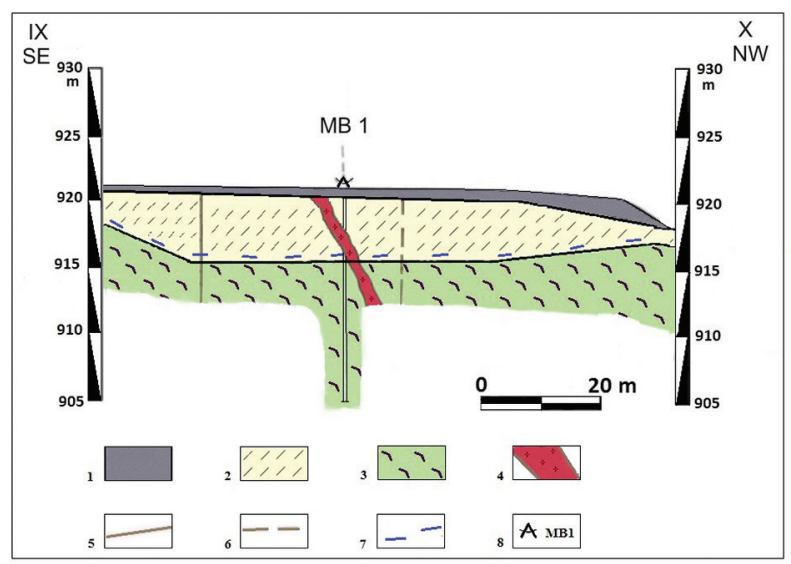

Fig. 3. Cross-section through the RAW Repository Novi Han (after Antonov and Varbanov, 2013, with amendments): 1 Anthropogenic embankment - first engineering geological zone EGZ (EGZ 1); 2 - Highly weathered rock-core (EGZ 2); 3 - Rock-core, phyllites weathered in different degree (EGZ 3); 4 - Fissured phyllites (argillites), in association with quartz dykes and granitoids (EGZ 4); 5 - Fault; 6 - Fault distinguished by geophysical surveys; 7 - Groundwater level; 8 - Motor borehole.

upper part of the weathered zone (between $7 \mathrm{~m}$ and $13.5 \mathrm{~m}$ in total).

- Phreatic zone. The phreatic zone underlies the vadose zone and it is formed in the fractured parts of the Ordovician phyllites.

\section{METHODOLOGY OF THE RESEARCH}

The constructed model will be implemented in programs numerically solving the partial differential equations for the governing convection-dispersion equations of the same-named model. Hence, the computer code HYDRUS-1D (Šimůnek et al., 2008) will be used for the vadose zone transport modeling and, respectively, the codes ModFlow (Hughes et al., 2017; Langevin et al., 2017) and MT3D-MS (Bedekar et al., 2016) will be used for the saturated zone transport modeling (Stoyanov, 2019).

\section{Characterization of the vadose zone and its hydraulic parameters}

The computer program HYDRUS-1D numerically solves (using the method of final elements) the advection-dispersion equation on the basis of the solution of the partial differential equation of Richards, which describes the water flow in a variably saturated porous medium (Šimůnek et al., 2008). Resolving the latter governing equation requires the knowledge of two nonlinear functions, namely the soil water retention curve $\theta(h)$ and the hydraulic conductivity function $K(h)$, and the theoretical fundamentals are given in brief.

The convection process in variably saturated porous medium is described by the partial differential equation of Richards. For one-dimensional vertical flow, this equation is:

$$
\frac{\partial \theta}{\partial t}=\frac{\partial}{\partial z}\left[K(h)\left(\frac{\partial h}{\partial z}+1\right)\right]
$$

where $\theta$ is volumetric soil water content $\left(\mathrm{m}^{3} \mathrm{~m}^{-3}\right)$; $t$ is time (s); $z$ is vertical coordinate (reference level for $h$ reading) (m); $K$ is hydraulic conductivity $\left(\mathrm{m} \mathrm{s}^{-1}\right)$; and $h$ is soil water pressure head (m).

Equation (1) is usually solved by the usage of the two above-mentioned nonlinear functions, $\theta(h)$ and $K(h)$. One of the most used and sustained models, empirically describing these functions and implemented in the HYDRUS-1D computer code, was developed by van Genuchten (1980) based on the statistical pore size distribution of Mualem (1976), and is defined as follows:

$$
\theta(h)= \begin{cases}\theta_{r}+\frac{\theta_{s}-\theta_{r}}{\left(1+(\alpha|h|)^{n}\right)^{m}} & , h<0 \\ \theta_{s} & , h \geq 0\end{cases}
$$

and

$$
K(h)= \begin{cases}K_{s} K_{r}(h) & h<0 \\ K_{s} & h \geq 0\end{cases}
$$

as

$$
K_{r}=S_{e}^{l}\left[1-\left(1-S_{e}^{1 / m}\right)^{m}\right]^{2}
$$

where $\theta_{r}$ is residual water content $\left(\mathrm{m}^{3} \mathrm{~m}^{-3}\right)$; $\theta_{s}$ is saturated water content $\left(\mathrm{m}^{3} \mathrm{~m}^{-3}\right) ; \alpha\left(\mathrm{m}^{-1}\right), n(-)$, and $m$ ( $m=1-1 / n)$ are empirical constants; $h$ is soil water pressure head (m); $l$ is empirical constant, assumed as equal to $0.5 ; K_{r}$ is relative hydraulic conductivity $(-)$; $K_{s}$ is saturated hydraulic conductivity $\left(\mathrm{m} \mathrm{s}^{-1}\right)$; and $S_{e}$ is saturation degree (-) given with:

$$
S_{e}=\frac{\theta-\theta_{r}}{\theta_{s}-\theta_{r}} .
$$

According to the van Genuchten model, if the five hydraulic characteristic parameters $\theta_{r}, \theta_{s}, \alpha, n$ and $K_{\mathrm{s}}$ are known, the two functions $\theta(h)$ and $K(h)$ could be described (van Genuchten, 1980). 

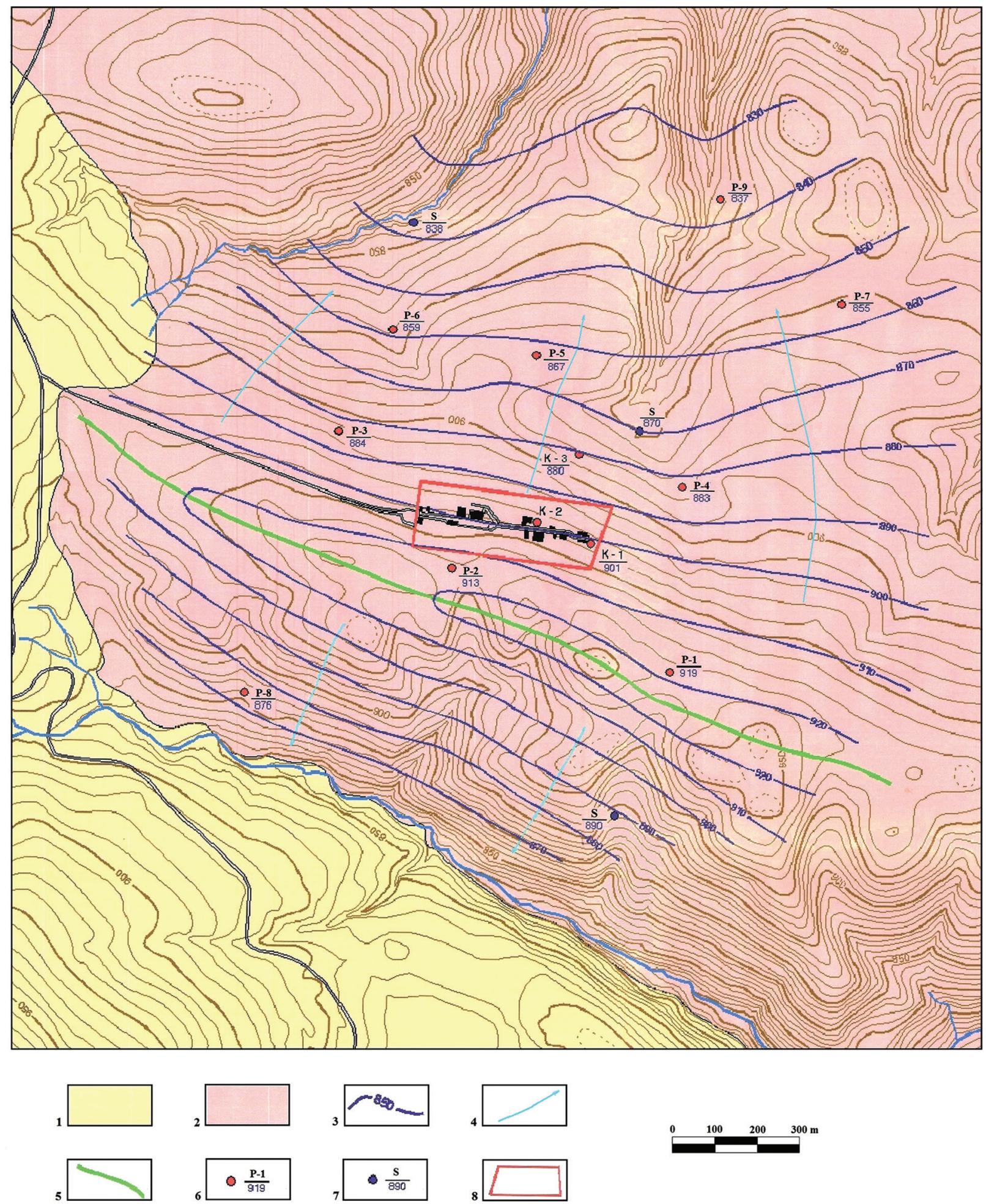

Fig. 4. Hydrogeological map of the RAW Repository Novi Han site (after Kozhoukharov et al., 2002, with amendments): 1 - Zone with prevailing groundwater in porous medium; 2 - Zone with prevailing groundwater in fractured medium; 3 - Groundwater table elevation; 4 - Groundwater flow line; 5 - Watershed; 6 -Piezometers - respectively, number and water level in meters; 7 - Spring (elevation in meters); 8 - Border line of the RAW Repository Novi Han. 
The values of these parameters for a relevant soil can be determined directly by field and/or laboratory hydraulic tests or estimated indirectly through prediction from more easily measured data based upon quasi-empirical models. Such models are known as pedotransfer functions (PTFs) because they translate basic soil data into hydraulic properties (Schaap and Leij, 1998; Schaap et al., 1998).

Such PTF algorithm based on particle-size distribution (PSD) analysis is used in the computer code ROSETTA (Schaap et al., 2001) incorporated in HYDRUS-1D. By using ROSETTA code, the retention function and the hydraulic conductivity function, i.e., their respective hydraulic parameters for each individual layer of the site/model, were determined.

\section{RESULTS AND DISCUSSION}

On the base of all gathered geological, engineering geological, borehole, and geophysical data from the ground site profile of RAW-Novi Han, four hydrogeological units with a different rank have been established. The domains of these units approximately coincide with the spatial ranges of the engineering geological zones described in Fig. 2 and Fig. 3.

The particles' percentage values (fractions) of sand, silt and clay based on the grain-size distribution curves (not presented in the study) of twentyfour samples in total of the different hydrogeological units gathered by three motor-boreholes MB1,
MB2 and MB3 (Fig. 2) on the site of RAW-Novi Han were used. In case of the existence of fractions greater than $2 \mathrm{~mm}$, their percentage values were added to the sand one. The latter approximation does not change the tendencies of the hydraulic characteristics, especially about the hydraulic conductivity ones, due to the similarity between the physical characteristics of the gravel- and sand-sized grains in a soil-rock complex. Then, each sample's fraction data were implemented in the ROSETTA program, and the respective hydraulic parameters were determined (Tables 1-3).

In summary, one set of hydraulic parameters was determined for the embankment, four sets of parameters were determined for the weathered rock (eluvium) all above the groundwater table, fourteen sets of hydraulic parameters were received for the phyllites zone all in the phreatic zone and, finally, five sets of parameters for the association of granitoids, phyllites and quartz dykes were determined in both the vadose and phreatic zones. Analysis of the received set of data shows that the hydraulic parameters' values of each specific unit in a specific place (borehole) are not dispersive, i.e., those of the weathered rock (Table 1), those of the association of granitoids and phyllites (Table 2), those of the phyllites (Table 2), etc. There is one exception for this tendency concerning the phyllites (Table 3 and partly Table 1). In contrast, the parameters' values for one and the same unit vary in spatial direction when comparing the hydraulic characteristics of MB1, MB2 and MB3, respectively. Thus, the spe-

Table 1

Hydraulic parameters determined by PTF analysis for MB1

\begin{tabular}{|c|c|c|c|c|c|c|}
\hline MB & depth & $\theta_{\mathrm{r}}$ & $\theta_{\mathrm{s}}$ & $\alpha$ & $\mathrm{n}$ & $\mathrm{K}_{\mathrm{s}}$ \\
\hline layer & (m) & $(-)$ & $(-)$ & $\left(\mathrm{m}^{-1}\right)$ & $(-)$ & $\left(\mathrm{m} \mathrm{s}^{-1}\right)$ \\
\hline $\begin{array}{l}\text { weathered rock } \\
\text { (eluvium) }\end{array}$ & $2.50-3.0$ & 0.0411 & 0.3847 & 4.03 & 1.6809 & $1.09 \mathrm{E}-05$ \\
\hline $\begin{array}{l}\text { weathered rock } \\
\text { (eluvium) }\end{array}$ & $6.0-6.50$ & 0.0374 & 0.3898 & 4.47 & 2.0064 & $1.88 \mathrm{E}-05$ \\
\hline $\mathrm{GWT}^{*}$ & \multicolumn{6}{|c|}{$6.9(\mathrm{~m})$} \\
\hline phyllites & $12.0-12.50$ & 0.0442 & 0.3823 & 3.83 & 1.8355 & $1.44 \mathrm{E}-05$ \\
\hline phyllites & $15.0-15.30$ & 0.043 & 0.3969 & 0.98 & 1.5156 & $2.98 \mathrm{E}-06$ \\
\hline phyllites & $17.0-17.30$ & 0.0393 & 0.386 & 4.11 & 1.6054 & $9.41 \mathrm{E}-06$ \\
\hline phyllites & 19.0-19.30 & 0.0396 & 0.3871 & 3.08 & 1.4071 & 4.96E-06 \\
\hline $\begin{array}{l}\text { phyllites and } \\
\text { quartz dykes }\end{array}$ & 21.0-21.30 & 0.0417 & 0.3841 & 3.86 & 1.5283 & 7.5E-06 \\
\hline $\begin{array}{l}\text { phyllites, high- } \\
\text { ly weathered }\end{array}$ & $22.50-23.0$ & 0.0411 & 0.3849 & 4.07 & 1.7984 & $1.36 \mathrm{E}-05$ \\
\hline phyllites & $26.50-26.80$ & 0.0363 & 0.3887 & 3.52 & 1.4255 & $6.05 \mathrm{E}-06$ \\
\hline phyllites & $29.30-29.50$ & 0.0529 & 0.3884 & 2.34 & 1.3884 & $2.64 \mathrm{E}-06$ \\
\hline phyllites & 29.50-30.0 & 0.052 & 0.3919 & 1.58 & 1.4364 & $2.14 \mathrm{E}-06$ \\
\hline
\end{tabular}

${ }^{*}$ GWT - groundwater table 
Hydraulic parameters determined by PTF analysis for MB2

\begin{tabular}{|c|c|c|c|c|c|c|}
\hline MB2 & depth & $\theta_{r}$ & $\theta_{s}$ & $\alpha$ & $n$ & $K_{s}$ \\
\hline layer & (m) & $(-)$ & $(-)$ & $\left(\mathrm{m}^{-1}\right)$ & $(-)$ & $\left(\mathrm{m} \mathrm{s}^{-1}\right)$ \\
\hline $\begin{array}{c}\text { Weathered } \\
\text { rock (eluvium } \\
\text { clay) }\end{array}$ & $1.0-1.20$ & 0.0433 & 0.3837 & 3.59 & 1.4463 & 5.69E-06 \\
\hline $\begin{array}{c}\text { association of } \\
\text { granitoids and } \\
\text { phyllites }\end{array}$ & 7.80-8.0 & 0.0341 & 0.3907 & 3.47 & 1.4228 & $6.45 \mathrm{E}-06$ \\
\hline $\begin{array}{c}\text { association of } \\
\text { granitoids and } \\
\text { phyllites }\end{array}$ & $8.0-8.50$ & 0.0325 & 0.3925 & 3.67 & 1.4319 & 7.09E-06 \\
\hline $\begin{array}{c}\text { association of } \\
\text { granitoids and } \\
\text { phyllites }\end{array}$ & $10.0-10.20$ & 0.0395 & 0.386 & 3.77 & 1.4586 & 6.30E-06 \\
\hline $\mathrm{GWT}^{*}$ & \multicolumn{6}{|c|}{$13.50(\mathrm{~m})$} \\
\hline phyllites & $14.0-14.50$ & 0.0414 & 0.3866 & 2.94 & 1.4026 & 4.53E-06 \\
\hline phyllites & $22.0-22.50$ & 0.0302 & 0.3958 & 4.33 & 1.4854 & 8.88E-06 \\
\hline phyllites & $27.50-28.0$ & 0.0413 & 0.3869 & 2.82 & 1.4023 & 4.44E-06 \\
\hline
\end{tabular}

*GWT - groundwater table

Table 3

Hydraulic parameters determined by PTF analysis for MB3

\begin{tabular}{|c|c|c|c|c|c|c|}
\hline & depth & $\theta_{\mathrm{r}}$ & $\theta_{\mathrm{s}}$ & $\alpha$ & $\mathrm{n}$ & $\mathrm{K}_{\mathrm{s}}$ \\
\hline layer & (m) & $(-)$ & $(-)$ & $\left(\mathrm{m}^{-1}\right)$ & $(-)$ & $\left(\mathrm{m} \mathrm{s}^{-1}\right)$ \\
\hline embankment & $1.0-1.50$ & 0.0426 & 0.3846 & 3.49 & 1.4271 & 5.29E-06 \\
\hline weathered rocks & $3.0-3.50$ & 0.0393 & 0.386 & 4.11 & 1.6054 & $9.41 \mathrm{E}-06$ \\
\hline $\mathrm{GWT}^{*}$ & \multicolumn{6}{|c|}{$10.15(\mathrm{~m})$} \\
\hline phyllites & $16.50-16.80$ & 0.0281 & 0.3997 & 4.37 & 1.4752 & 9.52E-06 \\
\hline phyllites & 21.0-21.30 & 0.0417 & 0.3903 & 1.73 & 1.4371 & 3.51E-06 \\
\hline phyllites & $26.0-26.30$ & 0.0378 & 0.3879 & 3.23 & 1.4128 & $5.46 \mathrm{E}-05$ \\
\hline phyllites & $29.70-30.0$ & 0.0413 & 0.3869 & 2.82 & 1.4023 & 4.44E-06 \\
\hline
\end{tabular}

${ }^{*}$ GWT - groundwater table

cial diversities should be taken into account for the next step of modeling.

\section{CONCLUSION}

Assessment of the potential radionuclide migration is a complex task due to the sophisticated mutual interactions of various elements and processes of a repository facility during time. In this study, an attempt has been made to describe in details the main features of the RAW-Novi Han's building and environment areas, e.g., engineered barriers and vadose and phreatic zones, that have to be integrated in a model case study. The concept of the latter is in congruence with the relevant international documents, especially those of the International Atomic
Energy Agency, and incorporates the governing equations of the water flow in media with variable state of saturation. In addition, as an initial stage of such model case study, after processing with ROSETTA program of samples' grain-size distribution fractions, the hydraulic parameters of the layers of four hydrogeological units, the constituents of the vadose and phreatic zones, are unambiguously determined. As a next step, the model will be implemented in two scenarios: with and without a source, i.e., radioactive waste facilities.

\section{Acknowledgements}

The authors express sincere thanks to the two anonymous reviewers for their valuable remarks and suggestions. 


\section{REFERENCES}

Antonov, D. 2017. Assessment of strontium transport in clay medium by using a reactive transport modelling approach - an HP1 case study model. Geologica Balcanica, 46 (2), 23-26.

Antonov, D., Varbanov, R. 2013. Geological and engineering geological settings of the radioactive waste repository Novi Han, Lozen Mountain, Bulgaria. Geologica Balcanica 42 (1-3), 75-84.

Bedekar, V., Morway, E.D., Langevin, C.D., Tonkin, M. 2016. MT3D-USGS version 1: A U.S. Geological Survey release of MT3DMS updated with new and expanded transport capabilities for use with MODFLOW. US Geological Survey, Reston, 69 pp. (https://dx.doi.org/10.3133/tm6A53).

Council of Ministers. 2011. Strategy for Spent Fuel and Radioactive Waste Management till 2030. Protocol 1.5 of the Council of Ministry, Sofia, 64 pp. (in Bulgarian).

Evstatiev, D., Petrov, P. Angelova, R., Karastanev, D. 1994. Geoenvironment assessment of radioactive waste repository. Proceedings of the 7th International IAEG Congress, 1994, Rotterdam, Balkema, 2403-2410.

Evstatiev, D., Kozhoukharov, D. 2000. Geological setting of the Novi Han radioactive waste storage site. Upgrading of Novi Han radioactive waste repository. International Workshop "Experience in the Upgrading of the Novi Han Radioactive Waste Repository", 27-30 November 2000, Borovets, Bulgaria, 1-9.

Galabov, M., Kovachev, S., Mavrodiev, B. 2003. Investigation on the migration ability of some radionuclides in groundwater. Annual of the University of Mining and Geology 46 (1), 223-226.

Hughes, J.D., Langevin, C.D., Banta, E.R. 2017. Documentation for the MODFLOW 6 framework. US Geological Survey, Reston, 40 pp. (https://doi.org/10.3133/tm6A57).

International Atomic Energy Agency. 1994. Sitting of near Surface Disposal Facilities. Safety Series Nr 111-G-3.1, IAEA, Vienna, $34 \mathrm{pp}$.

International Atomic Energy Agency. 1999. Near Surface Disposal of Radioactive Waste. Safety Requirements. Safety Standard Series Nr WS-R1, IAEA, Vienna, 30 pp.

International Atomic Energy Agency. 2004. Safety Assessment Methodologies for Near Surface Disposal Facilities. Results of a co-ordinated research project. Volume 1 - Review and enhancement of safety assessment approaches and tools. IAEA, Vienna. 413 pp. (https://www-pub.iaea.org/MTCD/ Publications/PDF/ISAM/IAEA-ISAM-Vol1_web.pdf).

International Atomic Energy Agency. 2006. Fundamental safety principles: Safety fundamentals. IAEA Safety Standards Series Nr SF-1, IAEA, Vienna, 24 pp.

International Atomic Energy Agency. 2011. Disposal of radioactive waste. IAEA Safety Standards Series Nr SSR-5, IAEA, Vienna, 62 pp.

International Atomic Energy Agency. 2014. Near surface disposal facilities for radioactive waste. IAEA Safety Standards Series Nr SSG-29, IAEA, Vienna, 124 pp.

Kozhoukharov, D. Evstatiev, D., Angelova, R., Todorov, K., Vassilev, E., Kozhoukharova, E., Yanev, S., Galabov, M., Hristov, V., Kovachev, S., Damyanov, A., Varbanov, R., Karastanev, D., Antonov, D., Shanov, S., Boykova, A. 2002. Geological, hydrogeological and engineering geological investigation of the site of PRRAW - Novi Han. Contract report, November 2002, Geological Institute fund materials, 115 pp. (in Bulgarian, unpublished).

Langevin, C.D., Hughes, J.D., Banta, E.R., Niswonger, R.G., Panday S., Provost, A.M. 2017. Documentation for the
MODFLOW 6 Groundwater Flow Model. US Geological Survey, Reston, 197 pp. (https://doi.org/10.3133/tm6A55).

Mallants, D., Marivoet, J., Sillen, X. 2001. Performance assessment of the disposal of vitrified high-level waste in a clay layer. Journal of Nuclear Materials 298 (1-2), 125-135.

Mallants, D., van Genuchten, M.Th., Šimůnek, J., Jacques, D., Seetharam, S. 2011. Leaching of contaminants to groundwater. In: Swartjes, F.A. (Ed.), Dealing with Contaminated Sites. Springer, Dordrecht, 787-850.

Mateeva, M. 2001. Preliminary safety assessment of the Novi Han radioactive waste repository. Termit $97 \mathrm{Ltd}$, Sofia, $176 \mathrm{pp}$.

Mateeva, M., Antonov, D. 2004. Prognosis of the radionuclide migration in the geological media of the Near Surface Repository for Radioactive Waste - Novi Han. Review of the Bulgarian Geological Society 65 (1-3), 47-54.

Merk, R. 2012. Numerical modeling of the radionuclide water pathway with HYDRUS and comparison with the IAEA model of SR 44. Journal of Environmental radioactivity 105, 60-69.

Mualem, Y. 1976. A new model for predicting the hydraulic conductivity of unsaturated porous media. Water Resources Research 12, 513-522.

Nuclear Regulatory Agency. 2011. Joint Convention on the Safety of Spent Fuel Management and on the Safety of Radioactive Waste Management. Fourth National Report, Sofia, 126 pp. (in Bulgarian).

Piqué, À., Arcos, D., Grandia, F., Molinero, J., Duro, L., Berglund, S. 2013. Conceptual and numerical modeling of radionuclide transport and retention in near-surface systems. Ambio 42 (4), 476-487.

Robinson, B.A., Bussod, G.Y. 2000. Radionuclide transport in the unsaturated zone at Yucca Mountain: Numerical model and preliminary field observations. In: Faybishenko, B., Witherspoon, P.A., Benson, S.M. (Eds), Dynamic fluids in fractured rocks. American Geophysical Union, Washington, D.C., Geophysical Monograph 122, 323-336.

Schaap, M.G., Leij, F.J. 1998. Using Neural Networks to predict soil water retention and soil hydraulic conductivity. Soil and Tillage Research 47, 37-42.

Schaap, M.G., Leij, F.J., van Genuchten, M.Th. 1998. Neural network analysis for hierarchical prediction of soil water retention and saturated hydraulic conductivity. Soil Science Society of America Journal 62, 847-855.

Schaap, M.G., Leij, F.J., van Genuchten, M.T. 2001. ROSETTA: a computer program for estimating soil hydraulic parameters with hierarchical pedotransfer functions. Journal of Hydrology 251, 163-176.

Šimůnek, J., Jacques, D., van Genuchten, M.T., Mallants, D. 2006. Multicomponent geochemical transport modelling using HYDRUS-1D and HP1. Journal of the American Water Resources Association 42(6), 1537-1547.

Šimůnek, J., Šejna, M., Saito, H., Sakai, M., van Genuchten, M.T. 2008. The Hydrus-1D Software Package for Simulating the Movement of Water, Heat, and Multiple Solutes in Variably Saturated Media. Version 4.0. HYDRUS Software Series 3, Riverside California: Department of Environmental Sciences, University of California Riverside, 315 pp.

Stefanova, I. 2003. Disposal of low- and intermediate level wastes. Termit $97 \mathrm{Ltd}$, Sofia, 311 pp. (in Bulgarian).

Stoyanov, N.T. 2009. Prognostication of mass-transport of radionuclides in the loess complex in the region of NPS "Kozloduy". Annual of the University of Mining and Geology 52 (1), 159-164 (in Bulgarian, with English abstract). 
Stoyanov, N.T. 2012. Model studies estimating the risk of a possible pollution in geological basis and groundwater caused by the designed National disposal facility for storage of radioactive waste in the region of NPS "Kozloduy". Annual of the University of Mining and Geology 55 (1), 140-145 (in Bulgarian, with English abstract).

Stoyanov, N.T. 2019. Mathematical modelling in hydrogeology. Numerical 3D models using finite difference method. "V. Ned- kov” Publishing House, Sofia, 246 pp. (in Bulgarian).

van Genuchten, M.T. 1980. A Closed-Form Equation for Predicting the Hydraulic Conductivity of Unsaturated Soils. Soil Science Society of America Journal 44, 892-898.

Vassilev, E., Kozhoukharov, D. 2004. New data on the stratigraphy of Neogene sediments in Lozen Mountain (Sofia District, Bulgaria). Comptes rendus de l'Académie bulgare des Sciences 57(3), 55-62. 